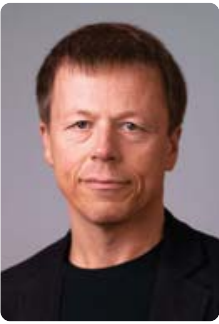

\title{
Kjære lesere
}

Selv $i$ et så fredelig hjørne av verden som Norge kan katastrofer, dramatiske hendelser eller terror ramme uten forvarsel, slik vi var vitne til den 22. juli i fjor. Slike hendelser setter dype spor. Like dype spor kan hendelser som rammer mennesker enkeltvis sette. Eksponering for ulike former for traumatisk stress forekommer dessverre langt hyppigere enn vi vanligvis tenker oss. I suicidologisk sammenheng ser vi likevel of te at traumene blir oversett hos personer som mottar behandling i tilknytning til suicidal atferd. Dette er uheldig siden klinisk erfaring og forskning gir klare holdepunkter for at slik traumeeksponering gir en langvarig $\varnothing \mathrm{kt}$ risiko for suicidal atferd. I dette nummeret av Suicidologi har vi valgt å fokusere på sammenhengen mellom traumer og suicidal atferd i ulike populasjoner og hvilke mekanismer som er involvert. I suicidologisk forskning kan et $ø$ kt fokus på psykiske traumer gi oss større kunnskaper om samspillet mellom individuelle sårbarhetsfaktorer og miljøbelastninger i utviklingen av selvmordsrisiko. Forhåpentligvis kan det også øke vår evne til å forebygge og til å hjelpe.

Mens 2012 ebber ut vil vi minne alle lesere om Verdenskongressen om selvmordsforebygging som arrangeres av NSSF i Oslo 24.-28. september neste år i samarbeid med den Internasjonale foreningen for selvmordsforebygging og WHO. Fristen for å melde på symposier og workshops er allerede 31. januar 2013. Tilsvarende frist for å melde på foredrag og postere er 31. mars 2013. Vi tar for gitt at mange norske fagmiljøer vil benytte anledningen til å legge fram sine erfaringer, prosjekter og resultater og markere seg sterkt. Unge forskere som under kongressen ønsker å få veiledning på sine manus fra et internasjonalt ekspertpanel kan innen 15.juli sende inn sine manusutkast for vurdering. Se www.iasp2013.org og vedlagte Second Announcement for detaljer. Dette vil bli det desidert største faglige arrangement av sitt slag i Norge noensinne. Vi håper mange vil sørge for å få det med seg. Med dette ønsker redaksjonen alle lesere og abonnenter en god julehøytid og et godt nytt år!

Lars Mehlum Redaktør

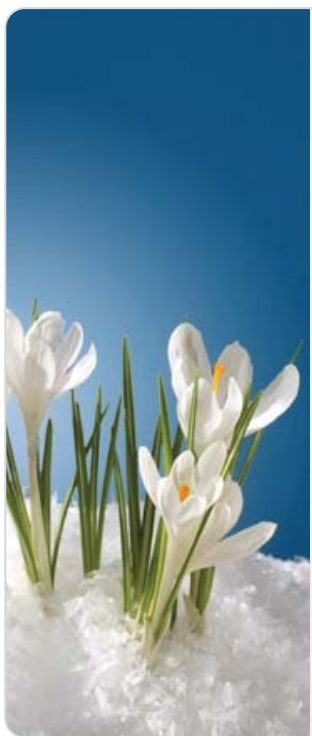

Suicidologi et fagfellevurdert tidsskrift

Vi vil takke følgende personer som har vurdert manuskripter for Suicidologi i 2012:

Gudrun Austad Jan Beskow Stian Biong Elin Anita Fadum Henning Herrestad Ingebjørg Hestetun Pravin Israel Bjørn Koldsland Asbjørn Kolseth Kim Larsen

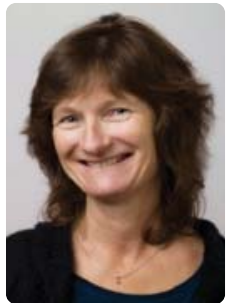

\section{Nytt fra NSSFs nettsider} www.selvmord.no

Ved Kirsti Amundsen

\section{Nye nettsider}

Nettsidene har fătt ny design og funksjonalitet. Nytt stoff er lagt ut for å imøtekomme ulike målgrupper, det være seg forskere, helsearbeidere, journalister og mennesker i krise. Flere pekere skal lette tilgangen til den store mengden med kunnskap som nettstedet rommer. Et nytt søkeprogram tilbys også.

\section{Krisehjelp}

En ny fellesside med krisehjelp er lagt ut, der det pekes til ulike tiltak og tekster for mennesker i krise.

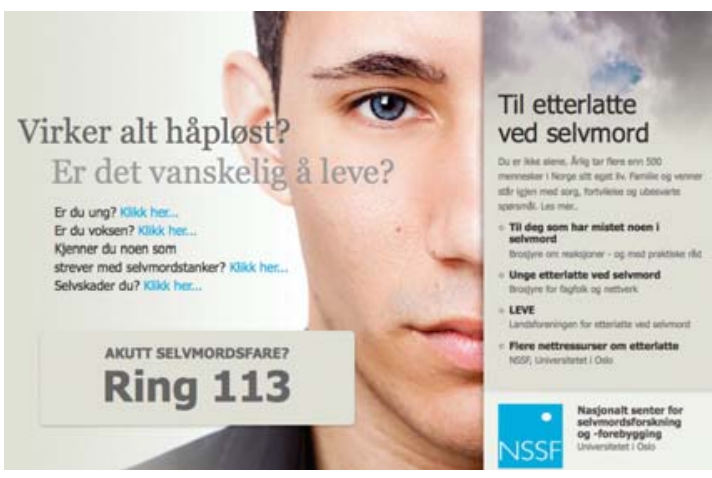

For pressen

Mediene er viktige samarbeidspartnere for NSSF når det gjelder å spre nøktern og korrekt informasjon om selvmord. De har nå fått egne sider med faktainformasjon om selvmord, smitteeffekter, myter om selvmord og pekere til veiledere for medier mm.

\section{Statistikk}

Dødsårsaksstatistikken for 2011 er lansert for Norge. Vi vil snart presentere aktuelle tabeller og grafer om selvmord. De viser aldersgrupper og kjønnsfordeling for flere tiår samt dødsmåte. En fylkesvis oversikt vil også legges ut.

\section{Aktuelt}

Her pekes det til aktuell forskning som NSSF har publisert samt til medieoppslag der NSSF har kommet med uttalelser. 